\title{
PENGARUH JARAK ANODA-KATODA PADA PROSES ELEKTROPLATING TEMBAGA TERHADAP KETEBALAN LAPISAN DAN EFISIENSI KATODA BAJA AISI 1020
}

\author{
Eko Budiyanto, Deva Agus Setiawan, Harnowo Supriadi, Kms. Ridhuan \\ Jurusan Teknik Mesin, Fakultas Teknik, Universitas Muhammadiyah Metro \\ Jl. Ki Hajar Dewantara 15 A Metro, Lampung \\ eko budiyanto99@yahoo.com, devaagus123@yahoo.co.id, harnowo123@yahoo.com, \\ kmsridhuan@yahoo.co.id,
}

\begin{abstract}
Abstrak
Pada proses elektroplating, tembaga banyak dipergunakan sebagai logam pelapis karena mempunyai sifat yang lunak, ulet, penghantar panas dan penghantar listrik yang baik. Karena sifatnya yang elektro positif, tembaga mudah diendapkan oleh logam yang deret gerak listriknya lebih tinggi. Tujuan dari penelitian ini adalah untuk mengetahui pengaruh jarak anoda-katoda terhadap ketebalan lapisan dan efisiensi katoda dalam proses elektroplating tembaga pada baja karbon rendah. Pada penelitian ini metode yang digunakan adalah studi lapangan, studi literatur, dan melakukan pengujian spesimen. Pengujian ini dilakukan di Loboratorium Teknik Mesin Fakultas Teknik Mesin Universitas Muhammadiyah Metro dan pengujian ketebalan lapisan dilakukan di Laboratorium Material Teknik Mesin Fakultas Teknik Universitas Lampung. Spesimen yang digunakan adalah baja AISI 1020 dengan ukuran $5 \times 2 \times 0,4 \mathrm{~cm}$ dan parameter jarak yang digunakan adalah $5 \mathrm{~cm}, 10 \mathrm{~cm}, 15 \mathrm{~cm}$ dan $20 \mathrm{~cm}$. Hasil penelitian menunjukkan bahwa variasi jarak anoda-katoda berpengaruh terhadap ketebalan lapisan dan efisiensi katoda. Semakin dekat jarak anoda-katoda, akan menghasilkan lapisan yang lebih tebal dan berlaku juga sebaliknya. Ketebalan maksimum didapatkan pada jarak $5 \mathrm{~cm}$ sebesar $0.108 \mathrm{~mm}$ dan efisiensi katoda tertinggi didapatkan pada jarak $5 \mathrm{~cm}$ sebesar $82.61 \%$.
\end{abstract}

Kata Kunci : Jarak Anoda-Katoda, Baja, Tembaga, Efisiensi Katoda, Elektroplating.

\section{Pendahuluan}

Kemajuan industri dan teknologi yang dicapai saat ini tidak terlepas dari peranan pemanfaatan logam sebagai material penunjang, baik logam murni atau logam paduan. Logam merupakan suatu bahan organik yang tidak dapat diperbaharui dan harus membutuhkan perawatan yang lebih sehingga bisa lebih tahan lama dalam penggunaannya. Berdasarkan perlakuan permukaan suatu material logam, mekanisme interaksi akan melibatkan pertukaran ion antara perlakuan logam dengan lingkungan atau disebut dengan korosi. Korosi merupakan masalah serius dalam penggunaan bahan dari logam, karena mengakibatkan bermacam macam kerusakan, salah satu contohnya adalah berkaratnya besi.
Terjadinya korosi ini berakibat penurunan mutu dan daya guna serta menimbulkan kerugian dari segi biaya perawatan. Korosi ini tidak dapat dicegah namun dapat dikendalikan. Upaya pengendalian yang lazim diterapkan dalam perlindungan terhadap logam yang digunakan adalah finishing dengan metode pelapisan pada logam. Prinsip pelapisan pada logam adalah semakin tebal pelapisan akan sangat mempengaruhi ketahanan dari umur matrial. Salah satu prinsip pelapisan pada logam diantaranya adalah dengan cara elektroplating dengan tembaga.

Proses elektroplating adalah proses pelapisan dimana terjadi pengendapan suatu pelapis logam tipis pada permukaan yang dilapisi menggunakan arus listrik searah (DC) dan tegangan yang konstan. 
Proses elektroplating dilakukan dalam bejana yang disebut sel elektrolisa berisi cairan elektrolit. Pada rendaman ini tercelup planting dua elektroda yang masing-masing dihubungkan dengan arus listrik, terbagi menjadi katub positif (+) dan negatif (-), yang dikenal sebagai anoda $(+)$ dan katoda (-). Anoda pada larutan elektrolit ada yang larut dan ada yang tidak. Anoda yang tidak larut berfungsi sebagai penghantar listrik saja, sedangkan anoda yang larut berfungsi selain penghantar arus listrik juga sebagai bahan baku pelapis. Katoda diartikan sebagai benda kerja yang dilapisi, dihubungkan katup negatif (-) sumber arus listrik. Elektrolit berupa larutan yang molekulnya dapat larut dalam air dan terurai menjadi muatan partikelpertikel bermuatan positif (+) atau negatif $(-)$.

Dalam proses elektroplating ada beberapa faktor atau variabel yang berpengaruh terhadap hasil pelapisan baik berupa tebal pelapisan ataupun tingkat kecerahan permukaan lapian. Dari sekian banyak faktor, lama waktu pelapisan jarak anoda-katoda, besarnya tegangan dan kuat arus mempunyai pengaruh yang cukup besar. Untuk hal tersebut dilakukan penelitian mengenai pengaruh faktor-faktor tersebut terhadap tebal hasil pelapisan. Semakin lama waktu pelapisan, semakin tebal hasil pelapisan, demikian juga semakin besar tegangan dan kuat arus, hasil pelapisan juga semakin tebal. Dari uraian tersebut, perlu dilakukan penelitian terhadap pengaruh jarak terhadap ketebalan lapisan dan efisiensi katoda pada proses elektroplating tembaga terhadap baja karbon rendah.

\section{Landasan Teori}

\section{Pelapisan Logam}

Pelapisan logam adalah suatu cara yang dilakukan untuk memberikan sifat tertentu pada suatu permukaan benda kerja dimana diharapkan benda tersebut akan mengalami perbaikan maupun ketahanannya serta tidak menutup kemungkinan pula terjadi perbaikan terhadap sifat fisiknya. Adapun macam macam pelapisan logam menurut tujuannya antara lain untuk mendapatkan sifat khusus pada permukaan.

\section{Elektroplating}

Elektroplating adalah suatu proses pengendapan atau deposisi onion logam pelindung (anoda) yang dikehendaki di atas logam lain (katoda) secara elektrolisa. Selama proses pengendapan berlangsung terjadi reaksi kimia pada elektroda (anodakatoda) dan elektrolit menuju arah tertentu secara tetap. Untuk hal tersebut dibutuhkan arus listrik searah (DC) dan tegangan yang konstan. Dapat disimpulkan bahwa terjadinya suatu endapan pada proses elektroplating ini disebabkan adanya ionion bermuatan listrik berpindah dari suatu elektroda (anoda) melalui elektrolit dan akan mengendap pada elektroda lain (katoda). Karena elektroplating adalah suatu proses yang menghasilkan lapisan tipis logam di atas permukaan logam lainnya dengan cara elektrolisis, maka perlu diketahui rangkaian dasar sistem elektroplating seperti yang tunjukkan pada Gambar 1.

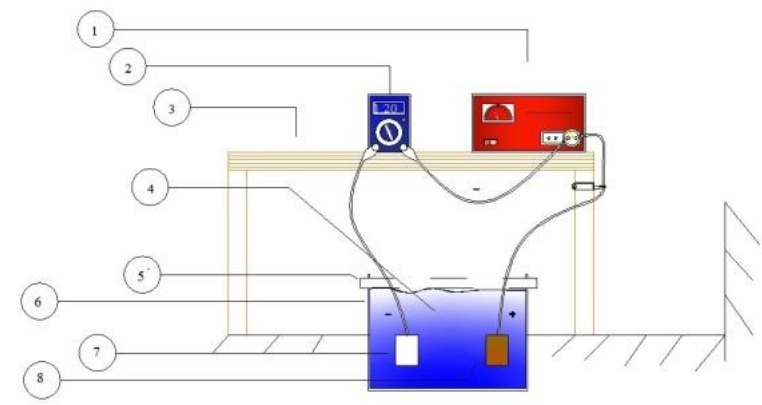

Gambar 1. Ilustrasi Alat Pelapisan

Keterangan:

1. Rectifier

2. Multitester digital

3. Rak

4. Larutan elektrolit

5. Penggaris

6. Bak

7. Katoda

8. Anoda

Besarnya listrik yang mengalir yang dinyatakan dengan Coulomb adalah sama dengan arus listrik dikalikan dengan waktu. 
Dalam pemakaian secara umum atau dalam pemakaian elektroplating satuannya adalah ampere-jam (Ampere-hour) yang besarnya 3600 Coulomb, yaitu sama dengan listrik yang mengalir ketika arus listrik sebesar 1 Amper mengalir selama 1 jam.

Michael Faraday pada tahun 1833 menetapkan hubungan antara kelistrikan dan ilmu kimia pada semua reaksi elektrokimia. Dua hukum Faraday ini adalah:

a) Hukum I : Jumlah dari tiap elemen atau grup dari elemen-elemen yang dibebaskan pada kedua anoda dan katoda selama elektrolisa sebanding dengan jumlah listrik yang mengalir dalam larutan.

b) Hukum II : Jumlah dari arus listrik bebas sama dengan jumlah ion atau jumlah substansi ion yang dibebaskan dengan memberikan sejumlah arus listrik adalah sebanding dengan berat ekivalennya.

Hukum I membuktikan terdapat hubungan antara reaksi kimia dan jumlah total listrik yang melalui elektrolit. Menurut Faraday, arus 1 Ampere mengalir selama 96.496 detik ( 26,8 jam) membebaskan 1,008 gram hidrogen dan 35,437 gram khlor dari larutan asam khlorida encer. Seperti hasil yang ditunjukkan bahwa 96.496 Coulomb arus listrik membebaskan satu satuan berat ekivalen ion positif dan negatif. Oleh sebab itu 96.496 Coulomb atau kira-kira 96.500 Coulomb yang disebut 1 Faraday sebanding dengan berat 1 elektrokimia. Untuk menentukan logam logam yang terdeposisi dengan arus dan waktu dapat ditentukan:

$$
\begin{aligned}
\text { Faraday } & =\frac{\text { Amper detik }}{96500} \\
& =\frac{\text { Amper jam } \times 3600}{96500}
\end{aligned}
$$

Langkah selanjutnya adalah mengalikan bilangan Faraday dengan bilangan gram yang diendapkan oleh 1 Faraday (gram ekivalen), maka persamaannya menjadi:

$$
\mathrm{W}=\frac{\mathrm{I} . \mathrm{t}}{96500} \times \frac{\mathrm{Ar}}{\text { valensi }}
$$

Dimana $\mathrm{W}=$ Massa endapan $(\mathrm{gram})$

$$
\begin{aligned}
& \mathrm{I}=\text { Arus (Amper) } \\
& \mathrm{t}=\text { Waktu (detik) } \\
& \mathrm{Ar}=\text { Masa atom }
\end{aligned}
$$

\section{Proses Pengendapan}

Beberapa segi penting pembentukan deposit plating ialah tentang potensial elektroda dan anoda terpolarisasi, sebelum beranjak ke tahap kajian berikutnya. Pertama-tama dapat disimak daftar deret daya gerak listrik terbagi unsur pada tabel berikut:

Tabel 1 Potensial standar elektroda (volt)

\begin{tabular}{|l|l|}
\hline \multicolumn{1}{|c|}{ Elektroda } & \multicolumn{1}{c|}{$\begin{array}{c}\text { Potensial } \\
\text { standard }\end{array}$} \\
\hline Litium $(\mathrm{Li})$ & $-3,045$ \\
\hline Rubidium $(\mathrm{Rb})$ & $-2,93$ \\
\hline Kalium $(\mathrm{K})$ & -2.924 \\
\hline Barium $(\mathrm{Ba})$ & $-2,90$ \\
\hline Strosium $(\mathrm{Sr})$ & $-2,90$ \\
\hline Kalium $(\mathrm{Ca})$ & $-2,87$ \\
\hline Natrium $(\mathrm{Na})$ & $-2,715$ \\
\hline Magnesium $(\mathrm{Mg})$ & $-2,37$ \\
\hline Alimunium $(\mathrm{Al})$ & $-1,67$ \\
\hline Mangan $(\mathrm{Mn})$ & $-1,18$ \\
\hline Seng $(\mathrm{Zn})$ & $-0,762$ \\
\hline Khrom $(\mathrm{Cr})$ & $-0,762$ \\
\hline Kadium $(\mathrm{Cd})$ & $-0,402$ \\
\hline Titanium $(\mathrm{Ti})$ & $-0,336$ \\
\hline Kobalt $(\mathrm{Co})$ & $-0,227$ \\
\hline Nikel $(\mathrm{Ni})$ & $-0,250$ \\
\hline Stanium $(\mathrm{Sn})$ & $-0,136$ \\
\hline Timbal $(\mathrm{Pb})$ & $-0,126$ \\
\hline Basi $(\mathrm{Fe})$ & $-0,441$ \\
\hline Platina $(\mathrm{Pt})$ & $+0,40$ \\
\hline Antimon $(\mathrm{Sb})$ & $+0,15$ \\
\hline Bismut $(\mathrm{Bi})$ & $+0,2$ \\
\hline Arsen $(\mathrm{As})$ & $+0,3$ \\
\hline Tembaga $(\mathrm{Cu})$ & $+0,34$ \\
\hline Raksa $(\mathrm{Hg})$ & $+0,789$ \\
\hline Perak $(\mathrm{Ag})$ & $+0,799$ \\
\hline Pladium $(\mathrm{Pd})$ & $+0,987$ \\
\hline Emas $(\mathrm{Au})$ & $+1,50$ \\
\hline & \\
\hline
\end{tabular}


Baja

Baja merupakan bahan garapan yang paling mudah diubah wujudnya. Oleh karena itu, baja paling banyak digunakan. Pabrik baja mengirimkan baja yang mutunya terjamin, sehingga untuk semua tuntutan dan maksud penggunaan senantiasa tersedia jenis baja yang cocok. Baja karbon adalah paduan besi dan karbon dimana unsur karbonnya sangat menentukan sifat mekanik dan fisik, sedangkan unsur paduan yang lainnya bersifat sebagai pendukung.

Tabel 2. Komposisi kimia dan material properties baja AISI 1045

\begin{tabular}{|l|c|c|}
\hline Element & \multicolumn{2}{|c|}{ Content } \\
\hline Carbon, C & \multicolumn{2}{|c|}{$0.420-0.50 \%$} \\
\hline Iron, Fe & \multicolumn{2}{|c|}{$98.51-98.98 \%$} \\
\hline Manganese, Mn & \multicolumn{2}{|c|}{$\leq .60-0.90 \%$} \\
\hline Phosphoruous, P & \multicolumn{2}{|c|}{$\leq 0.050 \%$} \\
\hline Sulfur, S & Metric & Imperial \\
\hline Physical Properties & $7.87 \mathrm{~g} / \mathrm{cc}$ & 0.284 \\
& & $1 \mathrm{~b} / \mathrm{in}^{3}$ \\
\hline Density & Metric & Imperial \\
\hline Mechanical Properties & 163 & 163 \\
\hline Hardness, Brinell & 184 & 184 \\
\hline $\begin{array}{l}\text { Hardness, Knoop } \\
\text { (converted from Brinell } \\
\text { hardness) }\end{array}$ & 84 & 84 \\
\hline $\begin{array}{l}\text { Hardness, Rockwell B } \\
\text { (converted from Brinell } \\
\text { hardness) }\end{array}$ & 170 & 170 \\
\hline $\begin{array}{l}\text { Hardness, Vickers } \\
\text { (converted from Brinell } \\
\text { hardness) }\end{array}$ & $140 \mathrm{GPa}$ & $20300 \mathrm{ksi}$ \\
\hline $\begin{array}{l}\text { Tensile Strength, } \\
\text { Ultimate }\end{array}$ & $565 \mathrm{MPa}$ & $81900 \mathrm{Psi}$ \\
\hline Tensile Strength, Yield & $310 \mathrm{MPa}$ & $45000 \mathrm{Psi}$ \\
\hline $\begin{array}{l}\text { Elongation at Break (in } \\
\text { 50 mm) }\end{array}$ & $16.0 \%$ & $16.0 \%$ \\
\hline Reduction of Area & $40.0 \%$ & $40.0 \%$ \\
\hline $\begin{array}{l}\text { Modulus of Elasticity } \\
\text { (Typical For Steel) }\end{array}$ & $200 \mathrm{GPa}$ & $29000 \mathrm{ksi}$ \\
\hline $\begin{array}{l}\text { Bulk Modulus (Typical } \\
\text { For Steel) }\end{array}$ & 0.290 & 0.290 \\
\hline $\begin{array}{l}\text { Poisson Ratio (Typical } \\
\text { For Steel) }\end{array}$ & & $11600 \mathrm{ksi}$ \\
\hline $\begin{array}{l}\text { Shear Modulus (Typical } \\
\text { For Steel) }\end{array}$ & $80 \mathrm{GPa}$ \\
\hline
\end{tabular}

\section{Tembaga}

Tembaga mempunyai sifat lunak dan ulet, tidak terlalu teroksidasi oleh udara.
Karena sifatnya pula yang elektropositif (mulia), tembaga mudah diendapkan oleh logam yang deret daya gerak listriknya lebih tinggi semisal besi. Misalnya sebuah plat baja karbon rendah akan dilapisi dengan tembaga dengan proses elektroplating. Elektrolit yang digunakan sebagai perantara adalah elektrolit tembaga dengan anoda tembaga $(\mathrm{Cu})$. Saat proses elektroplating, pada anoda dan katoda terjadi perubahan potensial akibat adanya aliran arus listrik searah, sehingga anoda tembaga akan terurai kedalam media larutan elektrolit yang mengandung ion-ion tembaga,yang akhirnya bergerak ke katoda dan akhirnya menempel kuat.

Pelapisan tembaga mudah dilakukan demikian pula dengan larutannya yang mudah dikontrol. Tembaga bagus sebagai lapisan dasar sebelum plating berikutnya. Tembaga relative inert terhadap berbagai larutan plating, maka logam dasar yang dapat diserang larutan tersebut dapat terlindungi bila di lapisi dengan tembaga terlebih dahulu. Secara elektrokimia berat terplat tiap satuan listriknya pada tembaga cukup baik dan besar, jadi lebih irit arusnya.

Beberapa reaksi atau proses yang terjadi adalah :

1. Reaksi pada larutan elektrolit :

Larutan elekrolit $\mathrm{CuSO}_{4}$ terurai menjadi ion $\mathrm{Cu}$ dan $\mathrm{SO}_{4}$. kation elektrolit $\left(\mathrm{SO}_{4}{ }^{2-}\right)$ menempel pada anoda. Reaksi ini dapat ditulis sebagai berikut :

$\mathrm{CuSO}_{4}----------->\mathrm{Cu}^{2+}+\mathrm{SO}_{4}^{2-}$

2. Reaksi pada katoda :

Pada plat baja karbon rendah mengalami pelepasan oksigen terhadap larutan tembaga $\left(\mathrm{CuSO}_{4}\right)$ akibat adanya arus listrik searah dengan tegangan konstan sehingga ion tembaga $(\mathrm{Cu})$ akan menempel pada permukaan plat dengan perantara elektrolit tembaga sehingga plat terlapisi tembaga. Reaksi yang terjadi pada katoda ini dapat ditulis :

$\mathrm{Cu}^{2+}+2 \mathrm{e}-$--------------> $\mathrm{Cu}$ 
3. Reaksi pada anoda

Reaksi yang terjadi pada anoda adalah bahan pelapis tembaga $(\mathrm{Cu})$ mengikat oksigen yang dilepaskan oleh plat baja karbon rendah. Bahan pelapis tembaga akan mengalami pengikatan yang kemudian akan terlarut pada elektrolit tembaga $\left(\mathrm{CuSO}_{4}\right)$ yang telah melapisi plat tersebut. Sehingga elektrolit tembaga $\left(\mathrm{CuSO}_{4}\right)$ tetap stabil, akibatnya bahan pelapis tembaga $(\mathrm{Cu})$ lama kelamaan akan berkurang atau habis. Kondisi pada anoda ini, dapat ditulis sebagai reaksi kimia berikut ini :

$$
\begin{aligned}
& \mathrm{Cu} \text {--------------> } \mathrm{Cu}^{2+}+2 \mathrm{e}- \\
& \mathrm{H}_{2} \mathrm{O} \text {--------------> } 2 \mathrm{H}++\mathrm{O}^{2-}
\end{aligned}
$$

\section{Analisa Ketebalan Lapisan dan Efisiensi Katoda}

Ketebalan adalah salah satu persyaratan penting dari suatu lapisan hasil elektroplating. Oleh karena itu, dari sekian banyak jenis pengujian yang dilakukan terhadap hasil plating, pengukuran ketebalan adalah salah satu uji yang harus dilakukan.

Ketebalan lapisan dicari dengan membaca hasil fotomikro dibaca dari microskop, Sementara itu secara matematis ketebalan lapisan yang terbentuk, dirumuskan sebagai berikut :

Dari rumus mencari berat endapan pelapis $(\mathrm{W})$, volume diperoleh dengan perhitungan

$$
\begin{gathered}
\text { Volume }\left(\mathrm{cm}^{3}\right)=\frac{\text { berat endapan }(\mathrm{gram})}{\operatorname{desitas}\left(\mathrm{gr} / \mathrm{cm}^{3}\right)} \\
\mathrm{V}=\frac{\mathrm{w}}{\rho}
\end{gathered}
$$

Densitas adalah kerapatan logam pelapis $\left(\mathrm{gr} / \mathrm{cm}^{3}\right)$. Dengan mengukur langsung permukaan benda kerja, maka ketebalan dapat ditentukan :

$$
\begin{aligned}
& \delta=\frac{\mathrm{V}}{\mathrm{A}} \\
& \delta=\frac{\text { I.t.B }}{\text { Z.F.A } \rho}
\end{aligned}
$$

Dengan,

$$
\begin{aligned}
& \delta=\text { Tebal lapisan terbentuk }(\mathrm{cm}) \\
& \mathrm{V}=\operatorname{Volume}\left(\mathrm{cm}^{3}\right)
\end{aligned}
$$

$$
\begin{aligned}
\mathrm{A}= & \text { Luas permukaan setelah dilapisi } \\
& \left(\mathrm{cm}^{2}\right) \\
\mathrm{F}= & \text { bilangan Faraday }(95.500 \\
& \text { A.dt } / \mathrm{mol}) \\
= & (96.500 \text { Coulomb })
\end{aligned}
$$

Jadi, rumus untuk menghitung laju ketebalan adalah sebagai berikut,

$$
\delta=\frac{\text { I.60.B }}{\text { Z.F.A. } \rho}
$$

Efisiensi plating pada umumnya dinyatakan sebagai efisiensi arus anoda dan katoda. Efisiensi katoda yaitu arus yang digunakan untuk mengendapkan logam pada katoda yaitu disebandingkan dengan total arus masuk. Arus yang tidak dipakai untuk mengendapkan logam-logam lain sebagai impuritas yang tidak diinginkan. Efisiensi anoda yaitu perbandingan antara jumlah logam yang terlarut dalam elektrolit sebanding dengan jumlah teoritis yang dapat larut menurut Hukum Faraday.

Kodisi plating dikatakan baik bila diperoleh efisiensi katoda sama dengan edisiensi anoda, sehingga efisiensi larutan bila menggunakan anoda aktif akan selalu tetap. Efisiensi arus anoda sering dipakai untuk mengendapkan ion logam pada katoda sehingga didapat efisiensi plating sebesar $100 \%$ atau lebih kecil. Adanya kebocoran arus listrik, larutan yang tidak homogen dan elektrolisis air merupakan beberapa penyebab rendahnya efisiensi.

Tebal lapisan yang terbentuk pada katoda dapat dihitung dengan persamaan berikut (Hakim,2005)

Dengan,

$$
\delta=\frac{\mathrm{v}}{\mathrm{A}}
$$

$$
\begin{aligned}
& \delta=\text { Tebal lapisan }(\mathrm{cm}) \\
& \mathrm{V}=\text { Volume lapisan yang menempel } \\
& \text { pada katoda }\left(\mathrm{cm}^{3}\right) \\
& \mathrm{A}=\text { Luas permukaan katoda yang } \\
& \text { terlapisi }\left(\mathrm{cm}^{2}\right)
\end{aligned}
$$

Efisiensi dituliskan sebagai berikut :

$$
\eta=W^{\prime} / \mathrm{W}
$$

Dengan,

$$
\mathrm{W}^{\prime}=\text { Berat nyata endapan pada katoda }
$$


$\mathrm{W}=$ Berat teoritis endapan pada katoda menurut Hukum Faraday.

\section{Metode Penelitian}

\section{Prosedur Pengujian}

Prosedur dilakukan dengan melalui serangkaian urutan kegiatan, diawali dengan kegiatan persiapan alat, bahan dan komponen penelitian komponen lainnya, sampai dengan pengujian hasil peneliatian, guna memperoleh data yang akurat mengenai penelitian yang dilakukan. Secara rinci, penelitian yang dilakukan dapat dijabarkan dalam urutan kegiatan sebagai berikut :

Persiapan pengujian

1. Membuat bak aquarium sesuai dengan desain,

2. Membuat dan merakit alat pelapisan,

3. Membuat spesimen uji dengan ukuran $5 \times 2 \times 0,4 \mathrm{~cm}$ (sebanyak 16 spesimen uji),

4. Amplas permukaan lempengan besi dengan gerinda tangan yang dipasang amplas kasar hingga bersih dan hilang seluruh karat yang menempel pada besi,

5. Bersihkan minyak dan lemak,

a. Cara pembuatan larutan pencuci lemak dan minyak antara lain: campurkan 12,9 gram $\mathrm{NaOH}$ dan 25 gram $\mathrm{Na}_{2} \mathrm{CO}_{3}$ kemudian larutkan dan tambahkan air hingga volume 1 liter,

b. Cara menghilangkan lemak dan minyak antara lain: celupkan lempengan besi yang telah diamplas dalam larutan pencuci lemak dan minyak pada suhu $70^{\circ} \mathrm{C}$ selama 15 menit.

6. Pembersihan karat yang pertama dengan cara membuat larutan penghilang karat dengan cara mencampurkan $20 \mathrm{~m} l \mathrm{H}_{2} \mathrm{SO}_{4}$ pekat dan larutkan dalam $80 \mathrm{~m} l$ aquades. Sedangkan yang kedua dengan cara menghilangkan karat dengan cara mencelupkan lempengan besi dalam larutan pencuci karat selama 15 menit pada suhu $40^{\circ} \mathrm{C}-60^{\circ} \mathrm{C}$.

7. Setelah pembersihan karat selesai, lakukan pembilasan dan penimbangan dengan cara membilas dengan air aquades sehingga lempengan bersih dari karat maupun lemak dan minyak. Selanjutnya keringkan lalu timbang berat awal menggunakan timbangan (neraca digital).

Tahap pelapisan

1. Pembuatan larutan elektrolit dengan cara mencampurkan 200 gram $\mathrm{CuSO}_{4}$ dan 30 gram $\mathrm{H}_{2} \mathrm{SO}_{4}$ kemudian larutkan hingga volume $1 \mathrm{l}$. $\mathrm{pH}$ larutan terukur 7 ( netral).

2. Sebelum mencelupkan benda uji, timbang terlebih dahulu berat benda uji awal dengan timbangan (neraca digital)

3. Proses elektroplating antara lain:

a. Hubungkan anoda pada katub positif dan katoda pada katup negative,

b. Anoda yang digunakan adalah tembaga dan katoda yang digunakan adala lempengan besi (benda yang akan dilapisi),

c. Celupkan anoda dan katoda pada larutan elektrolit dengan waktu 5 menit dan variasi terhadap jarak 5 $\mathrm{cm}, 10 \mathrm{~cm}, 15 \mathrm{~cm}$ dan $20 \mathrm{~cm}$,

d. Putuskan arus dan angkat benda uji,

e. Setelah benda uji diangkat, keringkan, kemudian timbang kembali dengan menggunakan timbangan (neraca digital)

4. Setelah proses elektroplating selesai, lakukan uji ketebalan lapisan dengan menggunakan microskop monitor LCD dan catat hasil yang didapat.

Peneliaian ini mengunakan variasi jarak terhadap arus, untuk sampai pada nilai efisiensi katoda maka dibutuhkan masa aktual lapisan dan masa teoritis lapisan. Besaran masa aktual lapisan didapat dari pengurangan masa akhir spesimen setelah dilapisi dikurangi masa awal spesimen 
sebelum dilapisi. Sementara besaran masa teoritis lapisan diperoleh dari rumusan Hukum Faraday. Ketebalan aktual lapisan adalah ketebalan lapisan rata-rata yang diperoleh dari hasil pengujian ketebalan lapisan di beberapa titik pada sempel yang diukur menggunakan microskop. Sedangkan ketebalan teoritisnya didapat dari penerapan Hukum Faraday.

\section{Hasil dan Pembahasan}

\section{Pengaruh jarak terhadap ketebalan}

Setelah melakukan pengujian maka dikumpulkan data-data yang diperoleh dari hasil plating dengan memvariasikan jarak katoda-anoda $5 \mathrm{~cm}, 10 \mathrm{~cm}, 15 \mathrm{~cm}$, dan 20 $\mathrm{cm}$. Pengujian ketebalan dilakukan dengan cara mengamati spesimen pada mikroskop optik, kemudian melakukan pemotretan. Setelah itu pengukuran ketebalan lapisan yang terbentuk pada permukaan tembaga dilakukan dengan cara mengukur lapisan pada poto hasil pemotretan sehingga dapat diketahui ketebalan lapisannya.

Tabel 3 Tebal lapisan

\begin{tabular}{|c|c|}
\hline $\begin{array}{c}\text { Jarak Pelapisan } \\
(\mathbf{c m})\end{array}$ & $\begin{array}{c}\text { Tebal Lapisan } \\
(\mathbf{m m})\end{array}$ \\
\hline 5 & 0.108 \\
\hline 10 & 0.1 \\
\hline 15 & 0.077 \\
\hline 20 & 0.058 \\
\hline
\end{tabular}

Jarak anoda-katoda adalah jarak yang menentukan hantaran arus listrik dan sangat berpengaruh terhadap keragaman tebal lapisan. Besarnya hantaran berbanding terbalik dengan jarak. Apabila jarak anodakatoda kecil, maka hambatan menjadi kecil dan konduktivitas besar sehingga untuk mendapatkan tapat arus yang besar diperlukan tegangan yang lebih rendah.

Dari data pengujian ketebalan lapisan Gambar 2. menunjukan hasil pengujian terhadap ketebalan lapisan permukaan yang dihasilkan pada proses pelapisan tembaga secara elektroplating. Berikut ini hasil persentasi tebal lapisan dari hasil elektroplating.

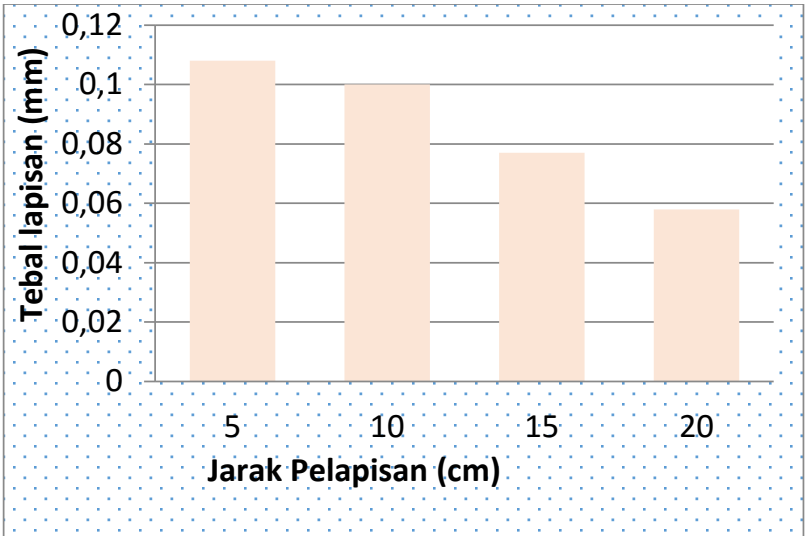

Gambar 2 Diagram ketebalan lapisan antara jarak terhadap ketebalan

Dari diagram diatas dapat ditulis dengan persamaan linier sebagai berikut:

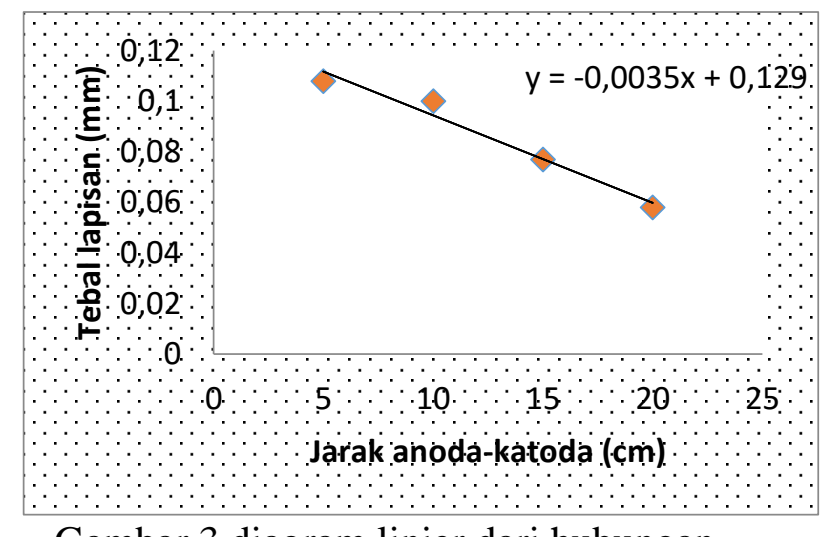

Gambar 3 diagram linier dari hubungan waktu terhadap tebal lapisan.

Berdasarkan hasil gambar 2 menunjukan adanya pengaruh jarak anodakatoda terhadap ketebalan lapisan yang terbentuk pada permukaan spesimen. Dengan mengamati hasil grafik di atas, ketebalan yang dihasilkan untuk keempat variasi jarak yang digunakan menunjukan 5 , 10 , 15 dan $20 \mathrm{~cm}$ menghasilkan 0.108 , $0.1,0.077$ dan $0.058 \mathrm{~mm}$. Hal ini disebabkan karena semakin pendek jarak elektroda maka hasil pelapisan yang terbentuk semakin besar sehingga daya ikat molekul antara baja karbon rendah dengan tembaga semakin kuat, sedangkan semakin besar jarak elektroda maka hasil pelapisan yang terbentuk semakin tipis sehingga daya ikat molekul antara baja karbon rendah dengan tembaga semakin lemah. Sedangkan pada gambar 3 pada diagram linier, diketahuai bahwa hasil yang 
diperoleh menunjukan semakin dekat jarak pelapisan sehingga menghasilkan hubungan jarak terhadap ketebalan lapisan yang sangat baik dan memiliki nilai persamaan yang dihasilkan dari diagram linier adalah $\mathrm{y}=-0.003 \mathrm{x}+0.129$.

\section{Efisiensi katoda}

Efisiensi katoda adalah perbandingan berat lapisan tembaga yang menempel pada katoda dalam penelitian dengan perhitungan secara teoritis. Maka dapat diliahat pada gambar 4 .

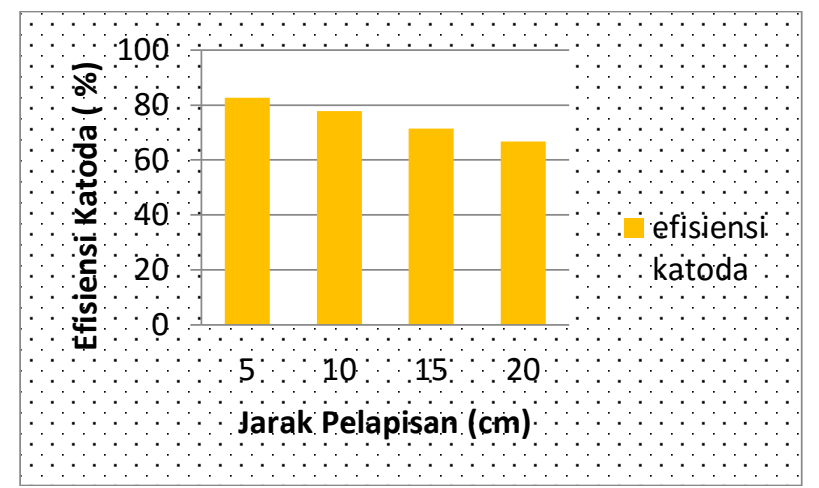

Gambar 4. Diagram hubungan antara jarak terhadap efisiensi katoda.

Pada gambar 4 didapat data bahwa tingkat efisiensi katoda pada proses pelapisan tembaga terhadap baja karbon rendah dengan elektrolit tembaga asam berat titik tertinggi pada jarak $5 \mathrm{~cm}$ mencapai $82,61 \%$ dan titik terendah pada jarak $20 \mathrm{~cm}$ mencapai 66,67\%. Sehingga semakin kecil jarak pelapisan maka hasil efisiensi katoda yang di hasilkan akan semakin maksimal sedangkan semakin besar jarak pelapisannya maka hasil efisiensi katodanya akan menurun.

Dari diagram diatas dapat ditulis dengan persamaan linier sebagai berikut:

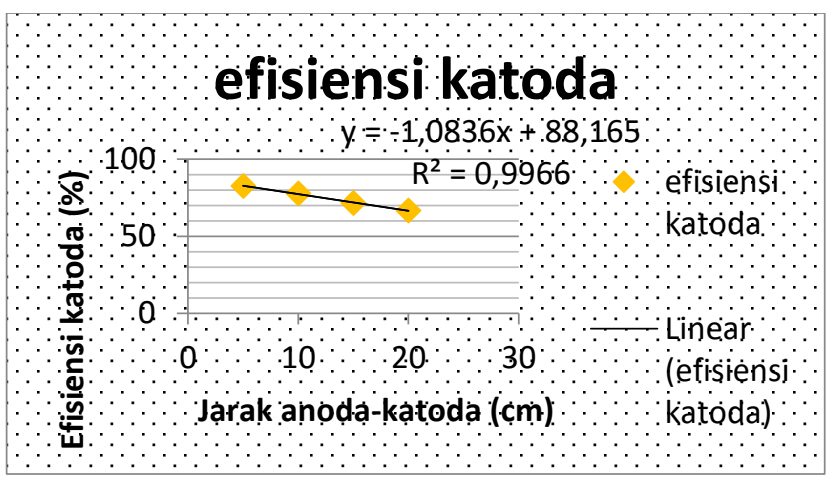

Gambar 5. diagram linier dari hubungan jarak terhadap efisiensi katoda

Sedangkan pada Gambar 5. pada diagram linier, diketahuai bahwa hasil yang diperoleh menunjukan bahwa semakin dekat jarak pelapisan menghasilkan hubungan jarak terhadap efisiensi katoda yang sangat baik dan memiliki nilai persamaan yang dihasilkan pada diagram linier adalah $\mathrm{y}=-1.083 \mathrm{x}+88.16$.

\section{Kesimpulan}

Dari hasil penelitian mengenai pengaruh variasi jarak anoda-katoda dari hasil elektroplating dapat disimpulkan sebagai berikut:

1. Semakin dekat jarak anoda-katoda maka semakin tebal pelapisan. Ketebalan paling maksimum didapatkan pada jarak $5 \mathrm{~cm}$ sebesar $0.108 \mathrm{~mm}$ sedangkan ketebalan minimum lapisan didapatkan pada jarak $20 \mathrm{~cm}$ sebesar $0.058 \mathrm{~mm}$. hal yang sama, berlaku pada besaran massa, nilai maksimum didapatkan pada jarak 5 $\mathrm{cm}$ sebesar 0.23 gram, dan nilai minimum pada jarak $20 \mathrm{~cm}$ sebesar 0.12 gram.

2. Efisiensi katoda tertinggi didapatkan pada jarak $5 \mathrm{~cm}$ sebesar $82.61 \%$ sedangkan efisiensi katoda yang terendah didapatkan pada jarak $20 \mathrm{~cm}$ sebesar $66.67 \%$.

\section{Daftar Pustaka}

[1] ASM Metals Handbook, 1994,"Surface Engineering”, volume 5.

[2] Callister Jr, William D,2007, "Material Science and Engineering", 
Department of Metallurgical Engineering The Universty of Utah.

[3] Davis, J.R., 2001,"Surface Engineering for Corrosion and Wear Resistance", ASM International

[4] Hartomo, J. Anton, 1992,“Mengenal Pelapisan Logam (Elektroplaiting)', Andi Ofset, Jogjakarta.

[3] Lowenheim, Frederick A.,1978, "Electroplating", McGRAW-HILL BOOK COMPANY, Kingsport Pres Inc.

[7] Rachim, Taufiq, 2001,"Spesifikasi, Metrologi, dan Kontrol Kualitas Geometrik", Institut Teknologi Bandung

[2] Van Vlack, Lawerench H., 1992,"Ilmu dan Teknologi Bahan", Erlangga, Jakarta. 